\title{
Immersion of grains in a liquid along an inclined plane
}

\author{
Viktor Saitov ${ }^{1,2, *}$, Vyacheslav Farafonov ${ }^{2}$, Aleksey Saitov ${ }^{1}$, and Rinat Gataullin ${ }^{1}$ \\ ${ }^{1}$ Federal Agrarian Scientific Center of the North-East, 166 A, Lenin str., Kirov, 610007, Russia \\ ${ }^{2}$ Vyatka State Agrotechnological University, 133, October ave., Kirov, 610017, Russia
}

\begin{abstract}
Grain material delivered from combine harvesters to postharvest processing points is a mixture of grain, weed and harmful impurities. Toxic ergot sclerotia are among the harmful impurities. Modern grain cleaning machines do not provide the separation of toxic ergot from grain material in one technological process. This is due to the closeness of the most toxic of ergot sclerotia and the of the grain. Ergot sclerotia are less dense than grain. Then the release of ergot from grain in one technological process is possible in an aqueous solution of salt. To develop a device for cleaning grain material by density in a liquid, practical experiments were carried out to supply grains of winter rye varieties Falenskaya 4 with a moisture content of $14 \%$ to an inclined plate placed in water. This plate mimicked the sloping bottom of an ergot seed separator. The statistical results of the experiments are presented by the distributions of the proportion of immersion of winter rye grains in water $(\rho z h=1000$ $\mathrm{kg} / \mathrm{m} 3$ ) over the surface of the inclined plate from the angle $\alpha$ of its inclination to the horizon. It has been established that $100 \%$ immersion of the grains in water occurs at an angle of inclination of the plate of $60^{\circ}$. When developing a machine for the extraction of ergot from rye grain, the angle of inclination of the bath bottom must be taken at least $65^{\circ}$ to the horizon for guaranteed immersion of grains in an aqueous solution of salt.
\end{abstract}

\section{Introduction}

Since ancient times, people have been using rye grain for cooking. Rye is also an excellent source of feed for farm animals. In industry, rye grain is used for the production of starch, and is also used as a raw material for the production of alcohols. Therefore, the production of rye grain is of great importance in the economic development of the Russian Federation, and ensures the country's security in the food market. However, rye crops during wet weather are often infected with ergot $[1,2]$.

Currently, the technology of rye grain production is sufficiently mechanized. The harvesting of this crop from agricultural fields is carried out by self-propelled combine harvesters, in which the threshed grain mass is accumulated in the bunker $[3,4,5]$.

Bunker grain heap of rye, in addition to high-grade grain, contains weeds. A separate fraction of weed impurities takes into account the harmful impurity, which includes ergot

\footnotetext{
* Corresponding author: vicsait-valita@e-kirov.ru
} 
sclerotia. They contain toxic substances that cause diseases in humans and animals, leading in some cases to death $[6,7,8]$.

Cleaning and sorting of a bunker grain heap of rye is based on the use of the physical and mechanical properties of its components, which include the geometrical dimensions of the grain (length, width, thickness and shape), the rate of soaring (aerodynamic properties) and the state of its surface, the specific gravity of the grain substance (density), color, flowability, electrical conductivity and others $[9,10,11,12,13,14]$.

Most of the physical and mechanical properties of rye grain and of toxic ergot sclerotia are comparable. Therefore, the existing grain cleaning machines, pneumosorting tables, and color separators do not provide complete separation of toxic ergot sclerotia in one technological process. In addition, further research by scientists to improve the technological process of these rye grain cleaning devices does not solve the noted problem [15-26].

However, poisonous ergot sclerotia differ in density compared to grain of rye. The density $\rho c$ of ergot sclerotia is $0.9 \ldots 1.15 \cdot 103 \mathrm{~kg} / \mathrm{m} 3$, and the density $\rho 3$ of rye grain is $1.2 \ldots 1.5 \cdot 103 \mathrm{~kg} / \mathrm{m} 3$. Therefore, in one technological process, practically $100 \%$ cleaning of rye grain from ergot sclerotia is possible in aqueous solutions of various inorganic salts. For the formation of solutions, mineral fertilizers can be used: potassium nitrate, ammonium sulfate, ammonium nitrate, sodium nitrate. To isolate ergot sclerotia from rye grain, solutions of sodium chloride or potassium salt can also be used [27].

This circumstance requires the creation of a less energy-intensive and more efficient machine for the isolation of toxic ergot sclerotia from rye grain. This machine must have an original design with the use of unified parts and assemblies, as well as simple, easy-toadjust and maintain main working parts [28].

One of the ways to solve this issue is to create a machine for the isolation of ergot from rye grain, consisting of a bath with an aqueous solution of salt, conveyors of seeds and waste, a hopper with a flap, a tank with an aqueous solution of salt and actuating mechanisms of working bodies [29].

When developing such a device to exclude the accumulation of grain on the bath wall, which impairs the technological process of separating rye grain from ergot sclerotia, it is necessary to determine the angle of inclination of the bath bottom to ensure that the grains are immersed in an aqueous solution of salt.

Therefore, the purpose of the study is to determine the angle of inclination of the bottom of the bath for guaranteed immersion of the grains in the liquid and to obtain the dependence of the distribution of the fraction of grains slipping from the inclined plate on its angle of inclination.

\section{Materials and methods}

To implement the set research goal, practical experiments were carried out on the supply of winter rye grains of the Falenskaya 4 variety with a moisture content of $14 \%$ into water with a density $\rho z h=1000 \mathrm{~kg} / \mathrm{m} 3$. For this, an experimental setup was made, which is shown in Figure 1.

The experimental setup for studying the immersion of grain in water along an inclined surface consisted of a laboratory stand 1, a bunker 3 , a bath 8 , and an inclined plate 9 installed on the end wall of the bath 8 . Laboratory stand 1 , consisting of a stand and a vertical stand, was additionally equipped with a counterweight 10 for giving stability. A holder 2 is fixed on the vertical post using a coupling with clamping screws, on which the bunker 3 is suspended.

Bunker 3 consists of vertical side, rear and end walls, an inclined bottom with an outlet with an adjusting flap 4 . The inclined bottom from the outlet is made in the form of a 
pitched plane 5. Bunker 3 is made with side dimensions of $0.1 \mathrm{~m}$ and a height of $0.23 \mathrm{~m}$. The angle of inclination of the bottom of the bunker 3, equipped with an outlet, is $60^{\circ}$ [30].

The bath 8 is made of transparent glass with a wall thickness of $0.005 \mathrm{~m}$. The side walls and the bottom of the bath 8 are glued together with a silicone-based sealant. The bath is a rectangular glass vessel having a length of $0.57 \mathrm{~m}$, a width of $0.21 \mathrm{~m}$ and a height of 0.34 $\mathrm{m}$. The volume of water poured into this vessel was 35 liters. The inclined plate 9 , installed on the end wall of the bath 8 under the bunker 3, is made with a width of $0.20 \mathrm{~m}$ and a length of an inclined surface of $0.21 \mathrm{~m}$. The inclined surface of the plate 9 was installed in the bath 8 at a depth of $0.07 \mathrm{~m}$ from the surface of the poured water with tilt angles 20,30, $40,50,60$ and 70 degrees according to the risks applied to the longitudinal wall of the bath 8. A sieve 7 was placed under the inclined plate 9 to collect the slipped grains from it.

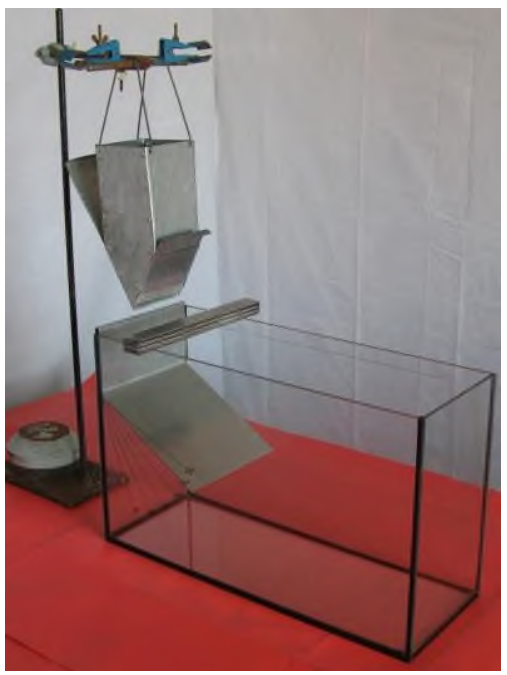

a

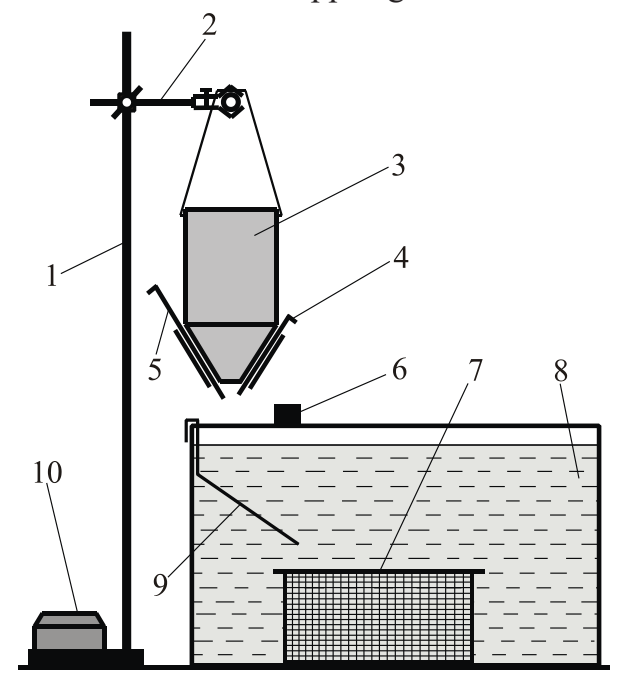

b

Fig. 1. General view (a) and diagram (b) of the experimental setup for studying the effect of the angle of inclination of the bottom of the bath on the immersion of grain in liquid: 1 -laboratory stand; 2 holder; 3 - bunker; 4 - adjusting flap; 5 - pitched plane; 6 - a set of metal plates; 7 - sieve; 8 - bath; 9 - inclined plate; 10 - counterweight.

Throwing of single grains in the amount of 20 pieces was carried out from a set of plates 6 , which were installed above the bath 8 . Feed the flow of grains of winter rye in the amount of 10000 pieces was carried out from bunker 3 with a specific grain load of 0.674 $\mathrm{kg} /(\mathrm{s} \cdot \mathrm{m})$, which corresponded to the opening of the outlet window of the bunker of the experimental installation 10.0 10-3 m. Single grains were thrown from a height of $0.055 \mathrm{~m}$, and the flow of winter rye grains was carried out from a height of $0.05 \mathrm{~m}$ and $0.6 \mathrm{~m}$ [31].

As a criterion for assessing the immersion of winter rye grains in water along an inclined plate, the proportion of grains descending from the inclined surface of this plate was taken $(\%)$ :

$$
P_{z}=\frac{n_{2}}{n_{1}} \cdot 100
$$

where $n 1$ - the amount of winter rye grains of the Falenskaya 4 variety entering the water, pc.;

$\mathrm{n} 2$ - the number of grains descended from the surface of the inclined plate to the bottom of the bath with water, pc. 
To obtain more reliable information, the experiments were carried out in three replicates. The temperature of the ambient air and the aqueous salt solution was $20^{\circ} \mathrm{C}$. The processing of the obtained experimental data was carried out on a personal computer using a package of office documentation programs for statistical information processing Microsoft Excel 2013. The resulting graphical dependencies were created in the vector graphics editor CorelDRAW 12.

\section{Results and discussion}

The dependences of the distribution of the share of $\mathrm{Pz}$ of immersion of winter rye grains of the Falenskaya 4 variety on the bottom of the bath with water $(\rho z h=1000 \mathrm{~kg} / \mathrm{m} 3)$ over the surface of the inclined wall from the angle $\alpha$ of its inclination to the horizon are shown in Figure 2.

When throwing individual grains from a height of $\mathrm{h}=0.055 \mathrm{~m}$ onto the water surface ( $\rho z h=1000 \mathrm{~kg} / \mathrm{m} 3$ ), the dependence of the distribution of the share of Pz,O55 immersion of winter rye grains of the Falenskaya 4 variety on the bottom of the bath along the surface of the inclined wall on the angle $\alpha$ of its slope is described by the equation (\%):

$$
P z, 055=-67.0+66.286 \alpha-6.429 \alpha 2, \quad R 2=0.930 ;
$$

and when the grain is fed by the flow, the dependences of the distribution of the fraction of Pz,P50 and Pz,P60 of the immersion of grains along the surface of the inclined wall to the bottom of the bath have the form (\%):

$$
\begin{array}{ll}
P z, P 50=-45.2+65.593 \alpha-7.036 \alpha 2, & R 2=0.971 ; \\
P z, P 60=-57.3+67.175 \alpha-6.912 \alpha 2, & R 2=0.962 .
\end{array}
$$

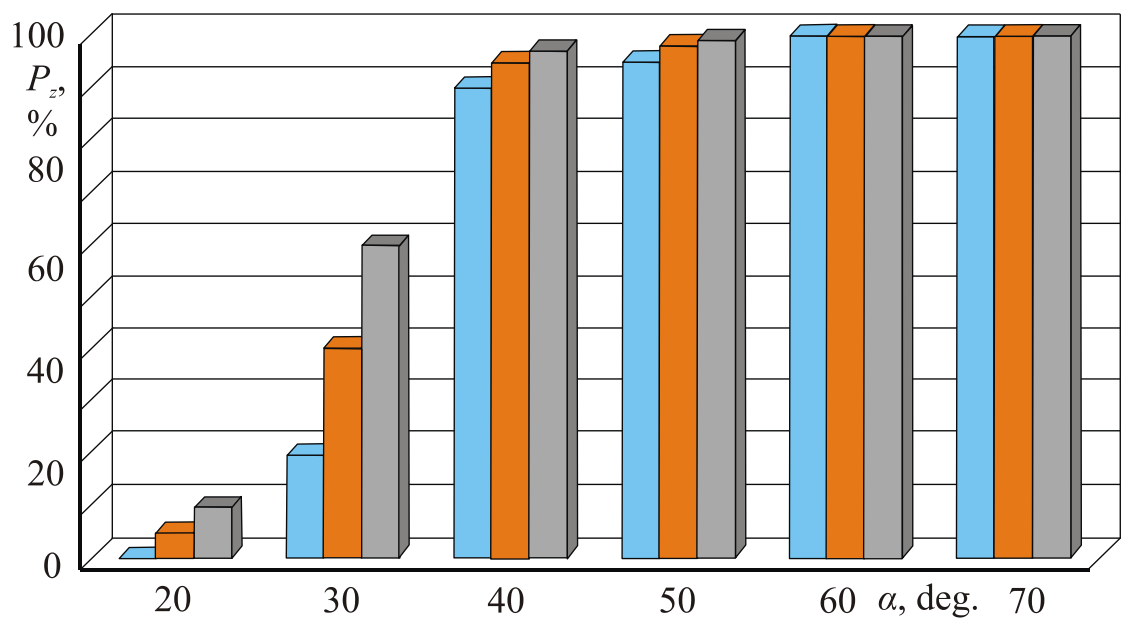

- when throwing individual grains from a height of $h=0.055 \mathrm{~m}$; when throwing individual grains from a height of $h=0.060 \mathrm{~m}$; individual grains from a height of $h=0.050 \mathrm{~m}$

Fig. 2. Dependences of the distribution of the share of Pz of immersion of winter rye grains of the Falenskaya 4 variety on the bottom of a bath with water $(\rho z h=1000 \mathrm{~kg} / \mathrm{m} 3)$ over the surface of the inclined wall on the angle $\alpha$ of its inclination to the horizon. 
The coefficient R2 of the reliability of approximation of dependence (2) is absolutely insignificantly less than 1.0. This indicates that the trend model is consistent with experimental data, which characterizes the approximation as a good quality regression model.

The coefficients R2 of the reliability of approximation of dependences (3) and (4) are practically close to 1.0 , which indicates a high degree of correspondence of the trend model to the experimental data. This characterizes the approximation as a practically reliable regression model.

From the obtained dependence (2), it follows that when single grains are thrown into a bath with water and immersed on the surface of an inclined plate installed at an angle of $\alpha=$ $20^{\circ}$ to the horizon, they do not roll off from it. All grains lie on the surface of the inclined plate due to the excess of the friction force of the grains on this plate over the component along this plate of the resultant of the remaining forces.

When the inclined plate is installed at an angle of $\alpha=30^{\circ}$ to the horizon, the grains entering its surface begin to move downward along it, being guided by the main major axis perpendicular to the direction of their movement. In this case, the sliding friction of the grain transforms into rolling friction, which is an order of magnitude less. As a result, $20 \%$ of the grains come off the inclined plate and enter the bottom of the bath.

If the inclined plate is installed at an angle of $\alpha=40^{\circ}$ to the horizon, the nature of the movement of grains along its surface remains the same as when the plate is installed at an angle of $\alpha=30^{\circ}$. However, some of the grains begin to move along the plate without rolling, but with sliding. In this case, $90 \%$ of the grains come off the inclined plate.

The installation of the inclined plate at an angle $\alpha=50^{\circ}$ to the horizon ensures that $95 \%$ of the incoming grains leave its surface. In this case, most of the grains move down the inclined with sliding and only single grains of a cylindrical shape roll.

Grain convergence in the amount of $100 \%$ occurs when the plate is installed at an angle $\alpha=60^{\circ}$ to the horizon or more. In this case, the grains move only with sliding, being guided by the main major axis perpendicular to the direction of movement. At an angle of installation of the plate $\alpha=70^{\circ}$ to the horizon, there is an inconsistent interaction of grains with the surface of the plate: a gap is observed between the grain and the surface of the plate when moving with a rare touch.

From expressions (3) and (4) it follows that when grain is fed by a stream to the water surface from a height of $\mathrm{h}=0.050 \mathrm{~m}$ and immersed on an inclined plate set at an angle $\alpha=$ $20^{\circ}$ to the horizon, the grains move along the length of the plate and are evenly distributed (Figure 3).

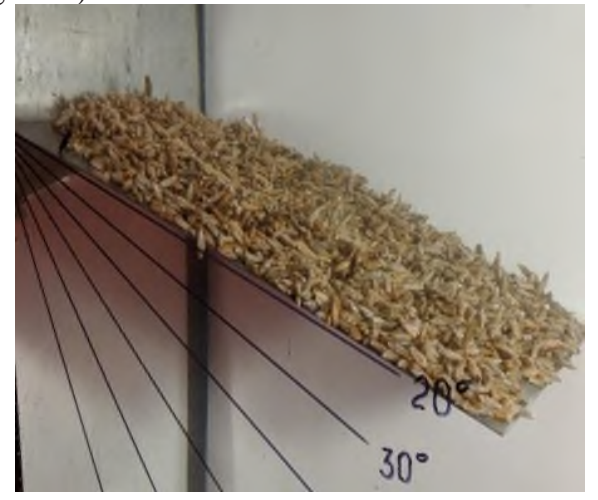

a

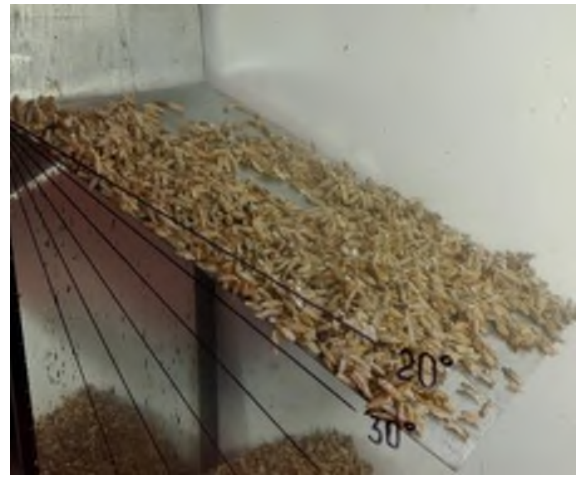

b

Fig. 3. General view of grains immersed on the surface of an inclined plate with an installation angle $\alpha=20^{\circ}$ (a) and $\alpha=30^{\circ}$ (b) to the horizon when grain is fed by a stream from a height of $h=0.050 \mathrm{~m}$. 
Some of the grains in the amount of $10 \%$ leave the plate due to the transfer of momentum by the grains immersed on it. In the case of feeding grain by a stream to the water surface from a height of $\mathrm{h}=0.060 \mathrm{~m}$, the amount of grains descending from the plate is no more than $5 \%$. This is due to the fact that a significant number of grains are immersed on the surface of the inclined plate with air bubbles. Air bubbles group the grains into lumps, then the adhesion of the grains to each other and the surface of the plate increases.

In addition, when the grains are immersed with air bubbles, the falling velocity of the grains decreases. Consequently, the impulse of such grains decreases, which they can transfer to the grains in front of them, which have already fallen on the inclined plate and therefore have reduced the speed of their movement. Grains with air bubbles move along the inclined plate at lower speeds than grains without bubbles and impede (slow down) the movement of subsequent grains. At small angles of inclination of the plate, this can lead to a stop of the flow of grains along the inclined plate.

Installation of the plate at angles $\alpha=30,40$ and $50^{\circ}$ to the horizon ensures that grain in the amount of 40.95 and $98.0 \%$ is removed from its surface when it is fed by a stream from a height of $h=0.060 \mathrm{~m}$, respectively, and 60.97 and $99.0 \%$ when fed from a height $\mathrm{h}=0.050$ $\mathrm{m}$, respectively. An increase in the amount of grain slipped from the inclined plate when it enters the water surface from a height of $\mathrm{h}=0.050 \mathrm{~m}$ is due to the exclusion of the capture of air bubbles by the grains, which significantly increase the adhesion properties of the grain with the plate surface.

The convergence of the grain flow from the surface of the plate installed at an angle of $\alpha$ $=60^{\circ}$ to the horizontal and more is $100 \%$. In this case, the flow of grain, when sliding along the length of the plate, disintegrates and quickly leaves it.

\section{Conclusion}

Thus, experimental studies indicate that when installing an inclined plate located in a bath with water, at an angle $\alpha=60^{\circ}$ to the horizon or more, the convergence of the grain from its surface is $100 \%$. When developing a device for the isolation of ergot sclerotia by density in a liquid for guaranteed immersion of the grain on the bottom of the bath with an aqueous solution of salt, the section of its bottom connecting the bottom under the conveyor for removing the rye seeds and the conveyor for removing ergot sclerotia should be taken at an angle $\alpha$ of at least $65^{\circ}$ to the horizon. Practical experiments carried out are consistent with theoretical studies [32].

The work was performed in the framework of the State task of the Federal Agrarian Scientific Center of the North-East (No 0767-2019-0094) «Creation of innovative technologies and technologies of a new generation for mechanization of crop and livestock production adapted to the climatic conditions of the North-East of the European part of Russia» and on the scientific topic «Physical and mathematical modeling of grain materials separation» of the Department of mathematics and physics of the Vyatka State Agrotechnological University (Kirov, Russia).

\section{References}

1. L.M. Schekleina, T.K. Sheshegova The problem of ergot grains (Claviceps purpurea (Fr.) Tul.): past and present (review), Theoretical and Applied Ecology 1, 5-12 (2013) DOI: http://doi.org/10.25750/1995-4301-2013-1-005-012 (In Russ.)

2. T.K. Sheshegova, L.M. Schekleina, E.I. Utkina, Immunological characteristics of varieties of winter rye, Agricultural science of the Euro-North-East 65(4), 30-35 (2018) DOI: https://doi.org/10.30766 / 2072-9081.2018.65.4.30-351 (In Russ.) 
3. V.I. Orobinsky, A.M. Gievsky, I.V. Baskakov, A.V. Chernyshov, Seed refinement in the harvesting and post-harvesting process, Adv. in Eng. Res. 870-874 (2018)

4. N. Aldoshin, O. Didmanidze, Harvesting Lupinus albus axial rotary combine harvesters, Res. in Agricul. Eng. 64(4), 209-214 (2018) DOI: http://doi.org/10.17221/107/2017-RAE

5. N. Aldoshin, O. Didmanidze, N. Lylin, M. Mosyakov, Work improvement of air-andscreen cleaner of combine harvester, Engineering for Rural Development: Proceedings of 18th International Scientific Conference 18, 100-104 (2019) DOI: http://doi.org/10.22616/ERDev2019.18.N110

6. L.M. Schekleina, T.K. Sheshegova, Ergot harmful in new varieties of winter rye in the Kirov region, Bulletin of Mari State University 2(14), 83-90 (2018) DOI: https://doi.org/10.30914 / 2411-9687-2018-4-2-83-89 (In Russ.)

7. L.M. Schekleina, The influence of weather factors on certain periods of development of the fungus Slavicep spurpurea (Fr.) Tul and the level of ergot erosion in the Kirov region, Agricultural science of the Euro-North-East 20(2), 134-143 (2019) DOI: https://doi.org/10.30766/2072-9081.2019.20.2. 134-143 (In Russ.)

8. T.K. Sheshegova, L.M. Schekleina, V.P. Zhelifonova, T.V. Antipova, B.P. Baskunov, A.G. Kozlovsky, The resistance of rye varieties to ergot and the content of ergot alkaloids in sclerotia claviceps purpurea in the conditions of the Kirov region, Mycology and phytopathology 53(3), 177-182 (2019) DOI: https://doi.org/10.1134 / S0026364819030127 (In Russ.)

9. M.S. Volkhonov, I.B. Zimin, Yu.N. Ostrovsky, Analysis of the state of preliminary cleaning of grain in farms of the north-western region of the Russian Federation and prospects for improvement, Bulletin of the Kazan State Agrarian University 15, 2(58), 82-86 (2020) DOI: https://doi.org/10.12737/2073-0462-2020-82-86 (In Russ.)

10. A.I. Burkov, A.L. Glushkov, V.A. Lazykin, Comparative studies of the effectiveness of the functioning of the pneumatic separation channels of the fractional pneumatic separator of seeds, Bulletin of the Voronezh State Agrarian University 12, 3 (62), 2631 (2019) DOI: https://doi.org/10.17238/issn2071-2243.2019.3.26 (In Russ.)

11. M.K. Kharitonov, A.M. Gievsky, V.I. Orobinsky, A.V. Chernyshov, I.V. Baskakov, Improving the efficiency of sieve cleaning of grain cleaning machines, Bulletin of the Voronezh State Agrarian University 13, 1(64), 19-27 (2020) DOI: https://doi.org/10.17238/issn2071-2243.2020.1.19 (In Russ.)

12. V.D. Galkin, A.D. Galkin, V.A. Khandrikov, A.F. Fedoseev, M.S. Nakaryakov, Parameters and modes of cleaning seeds on a vibro-pneumatic separator of improved design, Perm Agrarian Bulletin 1 (29), 4-12 (2020) DOI: https://doi.org/10.24411/2307-2873-2020-10012 (In Russ.)

13. V.E. Saitov, P. Savinyh, W. Golka, J. Kamionka, Increase of seed cleaning efficiency by better use of air stream properties, Agricultural Engineering 3(155), 89-99 (2015) DOI: http://dx.medra.org/10.14654/ir.2015.155.139 (in Russ.)

14. I. Badretdinov, S. Mudarisov, M. Tuktarov, E. Dick, S. Arslanbekova,Mathematical modeling of the grain material separation in the pneumatic system of the graincleaning machine, Journal of Applied Engineering Science 4(17), 529-534 (2019) DOI: https://doi.org/10.5937/jaes17-22640

15. V.I. Orobinsky, A.P. Tarasenko, A.M. Gievsky, A.V. Chernyshov, I.V. Baskakov, Improving the mechanization of high-quality seed production, Advances in Engineering Research 849-852 (2018) DOI: https://doi.org/10.2991/agrosmart18.2018 .159 
16. A.M. Gievsky, V.A. Gulevsky, V.I. Orobinsky, Ways to increase the performance of universal grain cleaning machines, Bulletin of the Federal State Educational Establishment of Higher Professional Education "Moscow State Agroengineering University named after VP Goryachkin" 3(85), 12-16 (2018) DOI: https://doi.org/10.26897 / 1728-7936-2018-3-12-16 (In Russ.)

17. P. Savinyh, Y. Sychugov, V. Kazako, S. Ivanovs, Development and theoretical studies of grain cleaning machine for fractional technology of flattening forage grain. In: Engineering for Rural Development: 17th International Scientific Conference Engineering for Rural Development, Proceedings 124-130 (2018) DOI: https://doi.org/10.22616/ERDev2018.17.N156

18. A.M. Gievsky, V.I. Orobinsky, A.P. Tarasenko, A.V. Chernyshov, D.O. Kurilov, Substantiation of basic scheme of grain cleaning machine for preparation of agricultural crops seeds, IOP Conference Series: Materials Science and Engineering 327, 042035 (2018) DOI: https://doi.org/10.1088/1757-899X/327/4/042035

19. V.E. Saitov, R.F. Kurbanov, A.N. Suvorov, Assessing the adequacy of mathematical models of light impurity fractionation in sedimentary chambers of grain cleaning machines, Procedia Engineering 150, 107-110 (2016) DOI: https://doi.org/10.1016/j.proeng.2016.06.728

20. V.E. Saitov, V.G. Farafonov, R.G. Gataullin, A.V. Saitov, Research of a diametrical fan with suction channel, IOP Conference Series: Materials Science and Engineering 473 (012009), 1-6 (2018) DOI: https://doi.org/10/1088/1757-899X/457/1/012009

21. V.L. Andreev, Calculation of the effective separation of light impurities in the inertial jalousie-countercurrent dust collector, IOP Conference Series: Materials Science and Engineering International Workshop «Advanced Technologies in Material Science, Mechanical and Automation Engineering» 32097 (2019) DOI: https://doi.org/10.1088/1757-899X/537/3/032097

22. V.I. Orobinsky, A.M. Gievsky, A.P. Tarasenko, A.V. Chernyshov, Study of strength and sowing qualities of seeds of winter wheat with fractional technology of postharvest grain processing, Bulletin of the Voronezh State Agrarian University 12, 62(3), 13-18 (2019) DOI: https://doi.org/10.17238/issn2071-2243.2019.3.13 (In Russ.)

23. Yu.I. Ermoliev, A.A. Doroshenko, S.V. Belov, Simulation of the process of separation of chopped straw in a pneumatic separator with three pneumatic channels, Bulletin of the Don State Technical University 16, 85(2), 59-68 (2016) DOI: https://doi.org/10.12737 / 19691 (In Russ.)

24. V.I. Orobinsky, A.M. Gievsky, A.P. Tarasenko, A.V. Chernyshov, I.V. Baskakov, A study of the effectiveness of cleaning heaps of spring wheat for seed purposes with an air-sieve separator, Bulletin of the Voronezh State Agrarian University 12, 61(2), 3442 (2019) DOI: https://doi.org/10.17238/issn2071-2243.0220019.2.34 (In Russ.)

25. A.I. Burkov, A.L. Glushkov, V.A. Lazykin, Calculation of particle trajectories in a pneumatic separation channel by various methods, Agrarian science of Euro-NorthEast 21, 1, 62-70 (2020) DOI: https://doi.org/10.30766/2072-9081.2020.21.1.62-70 (In Russ.)

26. M.K. Kharitonov, A.M. Gievsky, V.I. Orobinsky, A.V. Chernyshov, I.V. Baskakov, Studying the design and operational parameters of the sieve module of the grain cleaning machine, IOP Conference Series: Earth and Environmental Science 012021 (2020) DOI: https://doi.org/10.1088 / 1755-1315/488/1/012021

27. V.E. Saitov, V.G. Farafonov, A.V. Saitov, Experimental substantiation of the effective height of a grain falling by a stream of liquid in an ergot release device, IOP 
Conference Series: Earth and Environmental Science 341 (012123), 1-6 (2019) DOI: https://doi.org/10.1088/1755-1315/341/1/012123

28. K.D. Astanakulov, Y.Z. Karimov, G. Fozilov, Design of a grain cleaning machine for small farms, AMA, Agricultural Mechanization in Asia, Africa and Latin America 42(4), 37-40 (2011)

29. A. Saitov, R. Gataullin, V. Saitov, A machine for separating ergot from rye seeds, Patent RF no. 2689470 (2019)

30. V. Saitov, V. Farafonov, A. Suvorov, A. Saitov, Bulk material hopper, Patent RF no.2631556 (2017)

31. V.A. Sysuev, V.E. Saitov, V.G. Farafonov, A.N. Suvorov, A.V. Saitov, Theoretical background of calculating of the parameters of the device for grain cleaning from ergot sclerotia, Russian Agricultural Sciences 43(3), 273-276 (2017) DOI: https://doi.org/10.3103/S1068367417030156

32. V. Saitov, V. Farafonov, A. Saitov, Influence of the angle of the bath bottom inclination in ergot isolation device on grain immersion in a liquid, E3S Web of Conferences: Topical Problems of Green Architecture, Civil and Environmental $\begin{array}{lllll}\text { Engineering } & 164 & \text { (06004), } & 1-9 & \text { (2020) DOI:https://doi.org/ }\end{array}$ $10.1051 / \mathrm{e} 3$ sconf/202016406004 